\title{
Pablo Kreimer (2019) Science and Society in Latin America: Peripheral Modernities. New York and London: Routledge. ISBN: 9780367218034
}

\author{
Hebe Vessuri \\ hvessuri@gmail.com
}

The last few years have seen a growing number of works dealing with the global development of the social sciences. Pablo Kreimer, an Argentine sociologist of science, has published his latest book in English in order to engage in more direct conversation with the "global South". He not only chooses to place his concepts and ideas on an equal footing with those put forward in the (Northern) field's canonic literature, but also interrogates, addresses, and challenges it. This is not merely a conceptual contribution, but an attempt to break with the subaltern perception of science in the peripheries and the marginal place usually reserved for it in knowledge hubs around the world.

This is an honest, important, highly readable book. It spans twenty-five years of the author's personal intellectual development. The prints of his endeavors to investigate science, its social determinants and consequences, are clearly visible in what Dr. Kreimer calls his "pilgrimage" in STS.

Our paths crossed early in Kreimer's career, when he discovered what a few of us in Venezuela and Brazil were doing about something we used-in the absence of a better term-to call 'peripheral science' (Díaz et al., 1983). The perplexity then triggered in him by the study of molecular biology in his home country, Argentina, led him to embark on a long intellectual journey of exploration and reflection, and more recently to the idea of 'peripheral modernity'. He began by exploring Chagas disease as one of the earliest objects of research into Argentine and Brazilian molecular biology. The intriguing lack of use of locally produced knowledge that followed international canons in the Southern peripheries led him to study the tissue of international relations in an attempt to understand the processes of scientific development.

Among the central questions of his inquiry are: How do new disciplinary fields emerge? What kinds of relations are there between the construction of social problems and the formulation of scientific problems? How have relations between centers and peripheries changed in recent decades? At their heart is the long-standing tension between international knowledge production and the social utility of knowledge.

Kreimer tackles several problems while admitting that, in the final analysis, he is always addressing different facets of the same issues. In this sense, each chapter can be read as a contribution toward completing the image and strengthening the (always partial) view of certain aspects of reality that overlap with previous ones. But his travels, linked as they are to a need to explain the limited, local, situated, "peripheral", provincial, and parochial nature of his subject matter, have led him to explore the relevance and implications of his world-which is our own: Latin America-for the global field of the social studies of science.

For this book, he has selected texts with a pronounced reflective tone, written and rewritten over twenty-five years, charting the different stages of his intellectual journey. Following this 
itinerary, we can appreciate how his convictions slowly morph and change.

Kreimer's focus has always been Latin America, observing sometimes vast, sometimes fine differences in mainstream science. His concerns have led him to study science-oriented policy issues in an attempt to understand the roles played by science studies in science policies. His doctoral program evinced his interest in the microsociological analysis of research labs. He went on to study the construction of traditions through intergenerational filiation, and later, the relations between hegemonic and peripheral centers, an area that exercised him for many years.

He has repeatedly observed that the idea of the situated nature of knowledge seems not to have been internalized by Northern researchers. Their theoretical proposals were blithely unaware of the limitations in the social, economic, geographical or cultural contexts. Critical of cognitive domination by the major Northern knowledge centers, he sets about exploring the complexities of local, subaltern, provincial, "peripheral", sciences in Latin America, which he shows to be part and parcel of the international institution of science.

His Latin American perspective does not make him indifferent to what happens elsewhere on the planet. Kreimer argues that, if we do not take such dimensions into account, our alleged analysis of Science and Technology in Latin America will be limited and ultimately unreal. This international outlook pervades every chapter in the book, but particularly in Chapters 7, 8, and 9.

One can only applaud the differences in perspective and approach, and the social relevance of Kreimer's research into scientific practices in science hotspots around the world. In one project, he explores the current viewpoint and perception of Latin American scientists vis-à-vis their European counterparts in European research consortia. Two extremely interesting and valuable papers that came out of this project, are summarized for us by Kreimer here, in Chapter 8.

He examines the waning value of the region's S\&T policies' role. The elites of today's Latin American scientific communities are geared more to areas where they can collaborate with their European peers than to more "purely local" issues. Indeed, domestic research policies foster researchers' participation in European projects without setting a role for the thematic orientation of networks and projects. By bestowing a subordinate position on Latin American groups, European groups concentrate on the research design and are able to centralize their data and produce theoretical and conceptual interpretations. Moreover, the consortia rely on the participation of European business firms, from which it can be inferred that, if it occurs, the industrialization of knowledge will fundamentally benefit European firms and countries.

From a Latin American viewpoint, a crucial motivation for participating is closer ties with prestigious European research groups and the possibilities of coauthorship. Participation in European programs is highly unlikely to produce applied research to tackle local challenges. While some Latin American scientists may think there is no change in scientific agendas, the results of Kreimer's study suggest a process whereby local issues lose out to international ones in what begins to constitute a new global "science regime".

Of course, the effects of this differ considerably in the developed and developing countries. The situation is one of "outsourcing" of research work by countries with resources, which thereby maintain and increase their control. By contrast, the results for Latin American countries appear somehow absurd. The functionality of the interaction seems to be fairly minor: the production of papers in coauthorship and little else.

This, however, is part of the rigid academic evaluation system adopted by the region's science councils. In practice, it discourages an orientation toward thinking on the challenges of our countries' development under the mirage of blind participation in international cutting-edge science.

\section{References}

Díaz E, Texera Y and Vessuri H (1983) La ciencia periférica. Ciencia y sociedad en Venezuela. Caracas: Monte Ávila Editores. 